\title{
Physiological responses of two ecologically important Kenyan mangrove crabs exposed to altered salinity regimes
}

5

David Paul Gillikin ${ }^{1}$, Bart De Wachter ${ }^{2}$ and Jurgen F. Tack ${ }^{3}$

${ }^{1}$ Unit of Ecology and Systematics, Department of Biology, Vrije Universiteit Brussel, Pleinlaan 2, B-1050 Brussels, Belgium

${ }^{2}$ Ecophysiology and Biochemistry, Department of Biology, University of Antwerp

10 (RUCA), Groenenborgerlaan 171 U7, B-2020 Antwerp, Belgium

${ }^{3}$ Belgian Biodiversity Platform, Institute for Nature Conservation, Kliniekstraat 25, B-1070 Brussels, Belgium

15 Corresponding author: David Paul Gillikin

Email: david.gillikin@vub.ac.be

Fax: ++32-2-629-3274

Tel: $\quad++32-2-629-3968$

20 Current addresses:

${ }^{1}$ Department of Analytical and Environmental Chemistry, Vrije Universiteit Brussel, Pleinlaan 2, B-1050 Brussels, Belgium

${ }^{2}$ Environmental Consulting and Assistance NV, Lange Nieuwstraat 143, B-2000,

25 Antwerp, Belgium

Correspondence

David Paul Gillikin

Email: david.gillikin@vub.ac.be

30 Fax: ++ 32-2-629-3274

Tel: $\quad++32-2-629-3968$

Department of Analytical and Environmental Chemistry

Vrije Universiteit Brussel

Pleinlaan 2

35 B-1050 Brussels

Belgium

In Press Journal of Experimental Marine Biology and Ecology 40

Running head: Ecophysiology of two Kenyan mangrove crabs 


\section{Abstract}

The potential long-term effects of altered salinity regimes on the bioenergetics 45 of two ecologically important Kenyan mangrove crabs, Neosarmatium meinerti de Man, 1887 and N. smithi H. Milne Edwards, 1853 were investigated in light of recent findings suggesting that groundwater redirection may alter salinity regimes in Kenyan mangroves. Although changes in groundwater may cause only small increases in salinities, these changes would be chronic and may impact crab populations already

50 living above their optimal salinity. To assess potential impacts, fundamental physiological processes and hemolymph components were measured on animals acclimated to $16 \%, 32 \%, 48 \%$ and $65 \%$ for four weeks in a field laboratory. For comparative purposes, crabs were also sampled in the field. ․ smithi survived poorly in all salinities except the control (32\%). Although high mortality in $\underline{\mathrm{N}}$. smithi did not

55 allow for reliable estimations of an energy budget, mortality and osmoregulatory capacity shows that this species can osmoregulate for a limited time in elevated salinities ( \pm 1 week), but cannot withstand long-term hypersaline conditions. In

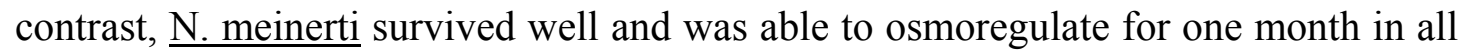
salinity treatments. Nevertheless, their energy budget, was significantly reduced (to

60 below zero) in the $65 \%$ o treatment. Overall, this study shows that these two congeneric species exhibit different long-term responses to variations in salinity. However, they are both negatively effected by hypersaline conditions, suggesting that long-term alteration of mangrove salinity regimes may be detrimental for these ecologically important mangrove crab populations.

\section{Keywords}

Ecophysiology $\cdot$ energy budget $\cdot$ osmoregulation $\cdot$ salinity tolerance $\cdot$ Sesarmidae 


\section{Introduction}

Crabs are the most abundant of the mangrove macro-fauna and are a valuable asset to the mangrove ecosystem. Crabs aerate the sediment by burrowing (Micheli et al., 1991), modify topography and grain size distribution (Warren and Underwood, 1986), reduce pore water salinity by allowing flushing of the sediment via their burrows (Ridd, 1996; Stieglitz et al., 2000), trap energy within the mangrove forest

75 (Robertson, 1986; Robertson and Daniel, 1989; Lee, 1998; Ashton, 2002), create microhabitat for other fauna (Bright and Hogue, 1972; Gillikin et al., 2001), contribute to secondary production (Lee, 1997), and increase the amount of nutrients and decrease the sulfide concentration in the sediment by a plethora of activities (Smith et al., 1991). Due to the critical role burrowing crabs play in the mangrove 80 ecosystem, Smith et al. (1991) considered them keystone species. In Kenya, two burrowing congeners, Neosarmatium meinerti and N. smithi, have opposing distributions across the mangrove forest (with $\underline{\mathrm{N}}$. meinerti inhabiting the high shore

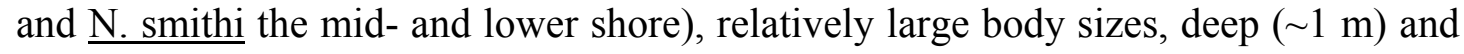
wide diameter ( $\sim 4$ to $5 \mathrm{~cm}$ ) burrows, and occur in high densities (Micheli et al., 1991;

85 Gillikin, 2000). Therefore, these two species probably play a very significant role in function and structure of Kenyan mangrove ecosystems.

Despite their importance, data on mangrove grapsoid ecophysiology remains patchy. Gross et al. (1966) showed that the mangrove crabs $\underline{N}$. meinerti and Cardisoma carnifex (Herbst, 1794) are powerful osmoregulators in both concentrated 90 and dilute media (concluded from a two day experiment), which would allow them to survive in the landward Avicennia marina (Forssk.) Vierh. zone subjected to periodic 
extreme salinity fluctuations. Although mangrove crabs usually show a distinct zonation, osmoregulatory ability has not been shown to be linked with the observed zonation patterns (Frusher et al., 1994) However, osmoregulatory ability may not be 95 enough to explain actual salinity tolerances. For example, the temperate estuarine crab Callinectes similis Williams, 1966, has been shown to be a strong osmoregulator, although scope for growth and long-term actual growth experiments show that the energy remaining for somatic growth is slightly reduced in higher salinities and is reduced by more than half in lower salinities (Guerin and Stickle, 1997a, 1997b).

100 Therefore, the long-term extra energy expenditure due to subtle, sublethal, effects of salinity may dictate long term salinity tolerances, especially for animals already living above their optimal salinity.

High evaporation and natural episodic fluxes of freshwater input into estuaries from meteorological events are common and often result in acute salinity fluctuations;

105 whereas anthropogenically induced changes in freshwater input result in chronic, if not indefinite, changes in estuarine salinity regimes (Christensen et al., 1997). Groundwater has been shown to contribute large amounts of water to estuarine water budgets, generally buffering salinity (Church, 1996; Moore, 1996). It is especially important in large riverine mangrove forests away from direct river input where water

110 circulation is reduced and evaporation is high. For example, Kitheka (1998) calculated that the backwater residence time was more than 11 days in Mida Creek, Kenya. Anthropogenic changes in groundwater outflow may be leading to changes in mangrove and seagrass distribution, community structure, faunal distribution and species richness (Kitheka, 1998; Kitheka et al., 1999; Tack and Polk, 1999; 115 Kamermans et al., 2002). Furthermore, the degree of community change induced by 
freshwater flow alterations is difficult to predict quantitatively because of the lack of field-based salinity range data available (Christensen et al., 1997).

Although there have been studies of acute osmotic stress tolerances of mangrove crabs (Gross et al., 1966; Frusher et al., 1994; Schubart and Diesel, 1998;

120 Anger and Charmantier, 2000), few studies have looked at chronic salinity tolerances. Since both growth and osmoregulation are energy requiring processes, the sublethal effects of chronic salinity stress may include changes in the energy budget of the animal. Physiological rates can be measured across a salinity gradient and converted to energetic equivalents to determine what effect salinity has on components of the 125 energy budget. An energy budget can then be estimated from energetic equivalents of fundamental physiological processes such as food uptake, excretion and oxygen consumption (Withers, 1992).

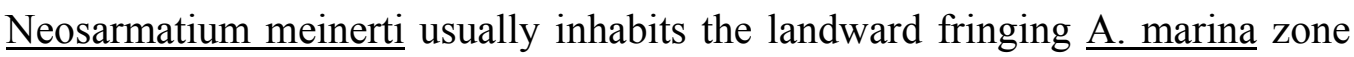
of the mangal, with large fluctuations in salinity and have been found inhabiting 130 salinities ranging from $1 \%$ to $65 \%$ (Gillikin, 2000). N. smithi occupy the lower broad Rhizophora mucronata Lam. zone, which is usually inundated daily and thus has a more stable salinity regime, but which may be as low as $21 \%$ and as high as $53 \%$ o (Gillikin, 2000). Both species are semi-terrestrial and are well suited for aerial respiration. They were chosen for this study due to their abundance, large size, wide 135 geographical distribution (see Davie, 1994) and fossorial mode of life. Much

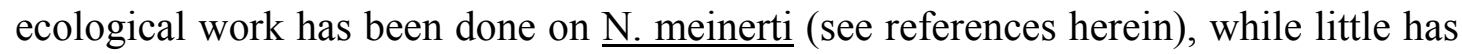

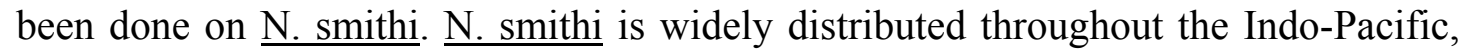
but has been wrongly identified in the south-western Pacific (e.g. Giddens, et al. 1986; 
Robertson and Daniel, 1989; Micheli, 1993) where it is replaced by its sister species 140 N. trispinosum (Davie, 1994).

The objective of the present study is to give insight into the possible long-term effects of altered salinity regimes on the bioenergetics of two of the potentially most important Kenyan mangrove crab species.

\section{Materials and methods}

\section{$\underline{\text { Laboratory methods }}$}

Intermolt adult specimens were collected in Gazi Bay, Kenya (S04 ${ }^{\circ} 5^{\prime}$ E039 ${ }^{\circ}$ 30’) (Fig. 1) in September 1999. Pore-water salinity was $\pm 32 \%$ in collection areas. Individuals of both species were captured by hand and were transferred to the field

150 laboratory within three hours, rinsed with seawater, blotted dry, sexed, weighed (to the nearest $0.01 \mathrm{~g}$ ) and carapace width $(\mathrm{CW})$ measured. Average weight and size of

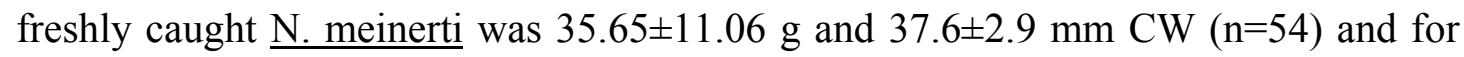

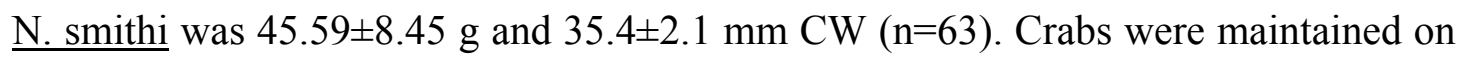
a 12-hour light-dark cycle in individual chambers $(20 \mathrm{~cm}$ diameter). Chambers were

155 filled with approximately one $\mathrm{cm}$ of water, which allowed them to replenish their branchial water, but not fully submerge themselves. During the collection period, crabs were maintained in natural seawater $( \pm 32 \%)$ and were offered fresh leaves (at least $5 \mathrm{~g}$ wet weight $(\mathrm{WW}))$. Water and food was changed daily. Water remained between 24.0 and $26.9^{\circ} \mathrm{C}$ with a $\mathrm{pH}$ between 7.0 and 8.0 throughout the experiment. 160 In Kenya, all laboratory work was conducted in a basic field station operated by the Kenya Marine and Fisheries Research Institute (KMFRI) located in Gazi Village, Kenya (about $40 \mathrm{~km}$ south of Mombasa). 
Ten crabs of each species were acclimated to one of four salinities (16\%o, 32\%o, 48\%o and 65\%o). Crabs were selected for the different salinities assuring similar

165 distribution of size and sex throughout the salinity range. Acclimation took place over four weeks; during the first week, stepwise increments were used to reach the target salinities (e.g. 2\%o to 5\%o per day). Water of different salinity was produced by either diluting filtered natural seawater with local well water or by adding natural sea-salt. Salinity was measured using a WTW multiline P4 conductivity meter. acclimation. Crabs were offered similar amounts of fresh green $\underline{\text { A. marina, }} \underline{\text { Ceriops }}$

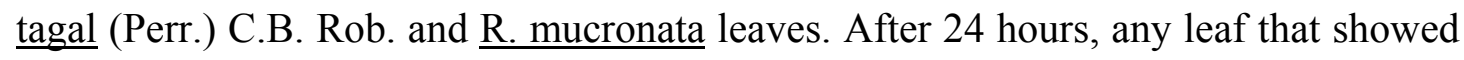
signs of feeding was considered eaten. Feeding preference studies were carried out for

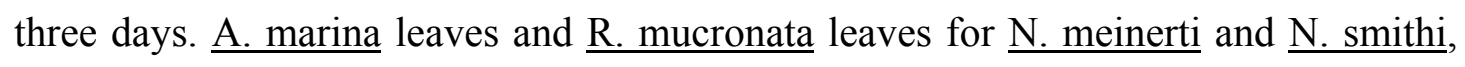
175 respectively, were used during the energy consumption experiment.

A simplified energy budget (E) in each salinity was estimated using the following equation:

$\mathrm{E}=\mathrm{FC}-(\mathrm{R}+\mathrm{U})$

where $\mathrm{FC}=$ energy consumed as food, $\mathrm{R}=$ respiration and $\mathrm{U}=$ excretion.

180 After four weeks of acclimation (three weeks at target salinities), energy consumed as food (FC), excretion (U) and oxygen consumption (R) rates were measured on all surviving crabs to allow an estimation of their energy budget.

Energy consumption experiments (FC) were carried out over three days, during which the crabs were offered 2-3 g WW of fresh green leaf material of their preferred 185 type. All leaves were collected daily, from the same two trees (from the same areas the crabs were collected) and WW was measured within one hour. Crabs were 
allowed to feed for a 24 hour period, after which leaves and leaf fragments were removed, blotted dry, dried at $60^{\circ} \mathrm{C}$ for 24 hours and weighed (leaves needed to be dried due to the water they absorbed during the experiment). To obtain regressions of 190 WW to dry weight (DW), additional leaves were treated in the same manner as above, except were placed in containers without crabs (for all salinities). For each salinity, two controls were used, one with whole leaves and one with shredded leaves to determine the effect of shredding by crabs and salinity on WW/DW conversions. Samples of dried leaves were returned to Belgium for calorimetric analysis (IKA195 calorimeter type C400). To determine feeding rates, initial leaf WW was converted into DW and the DW after feeding was subtracted. For A. marina leaves, initial WW was converted to DW using $\mathrm{DW}=0.388^{*} \mathrm{WW}\left(\mathrm{F}=314.9, \mathrm{p}<0.00001\right.$, adj $\mathrm{R}^{2}=0.93$, $\mathrm{n}=24)$. For $\mathrm{R}$. mucronata leaves, there was an effect of salinity $(\mathrm{F}=7.4, \mathrm{p}<0.01, \mathrm{n}=18)$, thus $\mathrm{DW}=0.278 * \mathrm{WW}+0.0044 *$ Salinity $\left(\mathrm{F}=98.05, \mathrm{p}<0.00001\right.$, adj $\left.\mathrm{R}^{2}=0.92\right)$.

200 Emmerson and McGwynne (1992) found that all fecal production of N. meinerti ceased after two days without food. Therefore, prior to the feeding experiment, crabs were starved for a minimum of 48 hours to purge their gut of food. An attempt was made to use the method of Conover (1966) to determine the energy absorbed from food (AE) (i.e., energy in food consumed minus the energy lost as ejecta or feces). 205 This is a simple method, which assumes that inorganic contents of the food are not taken up in the gut and can therefore be used as a tracer; thus, only the ratio of ashfree dry weight to dry weight in both the food and feces is required. However, this method gave very unsatisfactory results (all highly negative absorption efficiencies) and thus AE could not be determined (see Discussion). 
During the food consumption experiment, water samples were taken at the end of each day for determination of ammonia and urea excretion rates (U) (a standard method used to determine excretion; e.g., Lee and Chen, 2003). All containers (with crabs and controls) contained $100 \mathrm{ml}$ of water. Ammonia and urea analysis of water samples was performed colorimetrically using the phenol-hypochlorite method of 215 Solorzano (1969) and the diacetyl monoxime method of Rahmatullah and Boyde (1980), respectively. Standards were made up in chemically defined seawater of each salinity (as defined by Vercauteren and Blust, 1996). Detection limits for ammonium and urea were 6 and $3 \mu \mathrm{mol} \mathrm{1^{-1 }}$, respectively. Excretion rates were converted to energy expenditure rates using the factors of 0.0832 cal per $\mu$ mol of ammonia and $0.1544 \mathrm{cal}$

220 per $\mu \mathrm{mol}$ of urea, which are based on the standard heat of formation of each compound (Elliot and Davison, 1975).

Oxygen consumption (R) was determined by using the direct aerial method, where $\mathrm{CO}_{2}$ is absorbed by an alkali (in our case, $20 \%$ potassium hydroxide) (Dixon, 1934). Crabs were allowed to respire for at least five hours in respirometers with 100

$225 \mathrm{ml}$ of water $(\sim 1 \mathrm{~cm}$ deep). Data were collected after the crabs were allowed to settle from handling. Oxygen consumption rates were converted into energy expenditure using the oxycalorific value of 4.8 cal per $\mathrm{ml} \mathrm{O}_{2}$ consumed (Crisp, 1971).

Immediately after the respiration experiment, $1 \mathrm{ml}$ hemolymph samples were taken from the arthrodial membrane at the base of the $3^{\text {rd }}$ and $4^{\text {th }}$ walking legs with a 230 sterile 19-gauge hypodermic needle and syringe. Due to high mortality of $\underline{N}$. smithi in

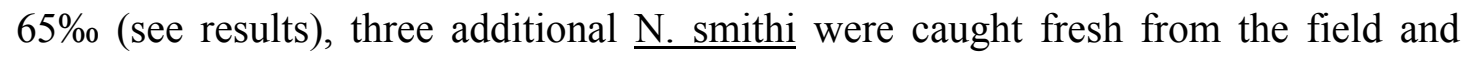
acclimated to $65 \%$ over a three day stepwise acclimation period. They were held at $65 \%$ for three days and hemolymph and water samples taken for measurement of the 
aforementioned variables. On occasion, obtaining hemolymph samples was difficult,

235 and for a few crabs impossible due to clotting. All hemolymph and water samples were immediately frozen at $-20^{\circ} \mathrm{C}$ until analysis in Belgium. Hemolymph urea was measured using the method above, while ammonia concentrations were determined using the Sigma ammonia test kit 171 (Sigma-Aldrich Co., Belgium). Using an ultraviolet endpoint, the fluorescence was read at $340 \mathrm{~nm}$ on a Spectra MAX Gemini 240 ultraviolet spectrophotometer (Molecular Devices Corp., USA), resulting in a detection limit of $50 \mu \mathrm{mol} \mathrm{NH}{ }_{4}^{+} 1^{-1}$. Osmolality of hemolymph and water samples was measured on a Fiske One-Ten Osmometer (Fiske Associates, USA) on $30 \mu 1$ of sample. All hemolymph and water samples were analyzed for $\mathrm{Na}^{+}, \mathrm{K}^{+}$and $\mathrm{Cl}^{-}$on an AVL 9180 Electrolyte Analyzer (AVL Scientific Corp., USA).

\section{Field methods}

Fieldwork took place in November 1999 in two Kenyan mangrove areas, Gazi Bay and Dabaso, Mida Creek (S03 ${ }^{\circ} 1^{\prime}$ E039 59') (Fig. 1). Kenya experiences a monsoonal climate with the majority of precipitation in Mombasa falling between

250 April and June $\left(\right.$ mean $\left.=192 \mathrm{~mm} \mathrm{month}^{-1}\right)$, with February and January being the driest months $\left(\right.$ mean $\left.=22 \mathrm{~mm} \mathrm{month}^{-1}\right)$; November receives $96 \mathrm{~mm} \mathrm{month}^{-1}$ on average (Lieth et al., 1999). Two sites were chosen in Dabaso, one for each species, whereas three sites were chosen in Gazi. Two of the sites in Gazi were the same as the collection areas of the laboratory experiment. The third site was chosen due to the 255 large difference between pore water $(\sim 60 \%)$ and $\underline{N}$. meinerti burrow water $(\sim 20 \%$ o $)$ salinity (indicating hypersaline burrow water during the dry season (cf. Stieglitz et al., 2000)). 
At each field site, at least nine crabs were sampled for hemolymph and three replicate water samples were taken from their burrows (when possible). Pore water

260 from nine bore-holes was taken from the area surrounding the sampled crab burrows. Hemolymph was sampled as in the laboratory. Only non-gravid adult intermolt specimens were used $(\underline{\mathrm{N} \text {. meinerti }}=35.7 \pm 3.1 \mathrm{~mm} \mathrm{CW}, \mathrm{n}=32 ; \underline{\mathrm{N}}$. smithi $=34.6 \pm 2.9 \mathrm{~mm}$ $\mathrm{CW}, \mathrm{n}=22)$. Hemolymph and water samples were stored in a cool box at $2{ }^{\circ} \mathrm{C}$ to $3^{\circ} \mathrm{C}$ during field work (for a maximum of three hours), then were treated the same as in the laboratory experiment. Pore water, burrow water and hemolymph were analyzed for urea, ammonia, osmolality and ion concentrations using the methods detailed above.

\section{$\underline{\text { Statistical analysis }}$}

After testing for a normal distribution using the Kolmogorov-Smirnov goodness 270 of fit test and homogeneity of variances using the multivariate Box M test, ANOVA was used to test for significance. The post hoc Least Squares Difference (LSD) test was used to test for differences between individual variables. Where appropriate, the Student t-test was used. All data analyses were carried out using Statistica 4.3D (Statsoft Inc.). Data are represented as means \pm standard deviations.

\section{Results}

\section{Laboratory}

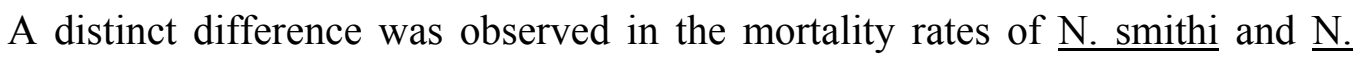

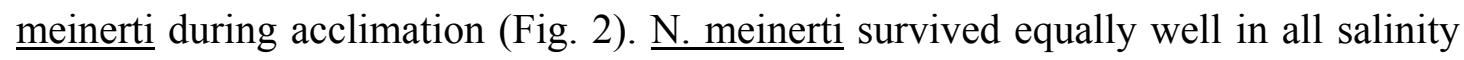

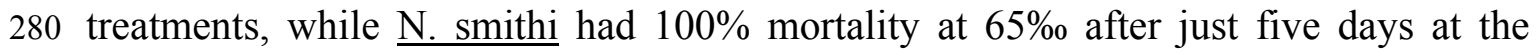


target salinity. Subjecting this species to $16 \%$ and $48 \%$ also resulted in high mortality

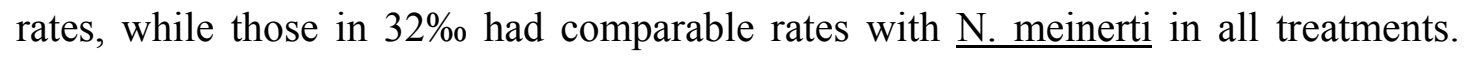
There was no significant weight change in any of the animals throughout the experiment, nor did any individual molt.

There was a clear preference in food choice for both species (Table 1). Salinity had a significant effect on food consumption of both species (ANOVA $\underline{\mathrm{N} \text {. meinerti }}$ $\mathrm{p}<0.001 ;$ N. smithi $\mathrm{p}<0.05$ ) (Fig. 3A). At the commencement of the feeding experiment, $\underline{N}$. meinerti in all salinities were very active and started to eat within

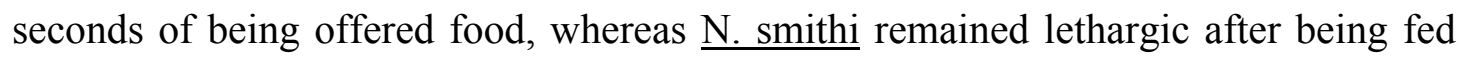
290 and only ate in the $32 \%$ and $48 \%$ treatments. Leaves of A. marina contained significantly more energy $\left(17.8 \pm 1.3 \mathrm{~kJ} \mathrm{~g}^{-1} \mathrm{DW}, \mathrm{n}=31\right)$ than $\underline{\mathrm{R}}$. mucronata leaves $\left(16.8 \pm 0.4 \mathrm{~kJ} \mathrm{~g}^{-1} \mathrm{DW}, \mathrm{n}=10\right)$ (student-t, $\mathrm{p}=0.02$ ).

At the highest salinity, both species showed significantly lower nitrogen excretion (LSD, $\mathrm{p}<0.05$ ) (Fig. 3B). Respiration was significantly lower in $16 \%$

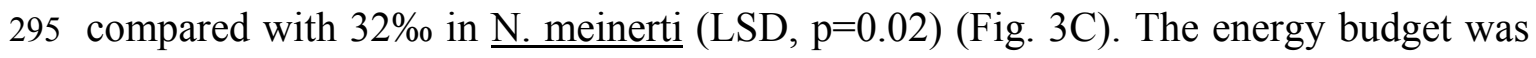
significantly affected by salinity in N. meinerti (ANOVA, $\mathrm{p}<0.001$ ) and was negative in all salinities for N. smithi (Fig. 3D).

Both species regulated their internal osmolality at all salinities, except $\underline{\mathrm{N} \text {. smithi }}$ at $32 \%$. N. meinerti had much lower hemolymph osmolalities and ion concentrations

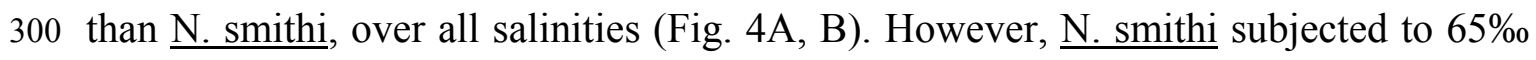

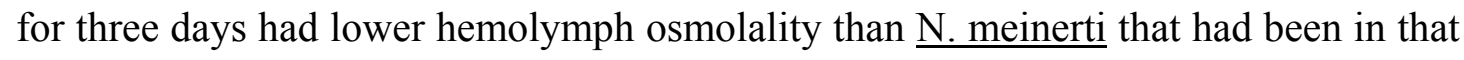
salinity for one month (ANOVA, $\mathrm{p}<0.05$ ). There was no difference observed in $\mathrm{K}^{+}$ concentration in either species used in the energy budget experiment, however it was significantly lower in the $\underline{N}$. smithi subjected to $65 \%$ o for only three days, when 


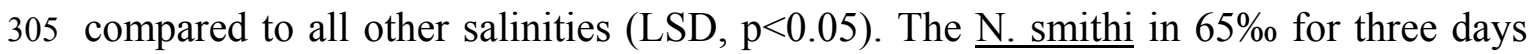
had similar $\mathrm{Na}^{+}$and $\mathrm{Cl}^{-}$concentrations compared to individuals in other salinities (Fig. 4A).

Ammonia concentrations in hemolymph were significantly higher in $\underline{\mathrm{N}}$. smithi

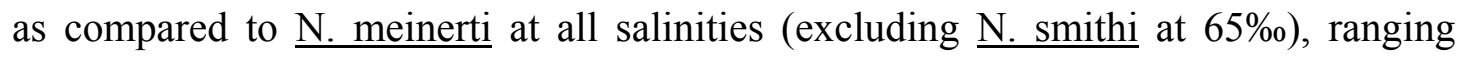

310 from 4.5 to 6.5 times higher (ANOVA, p<0.0001) (Fig. 5A). N. meinerti had increased levels of ammonia in 65\% compared to all other salinities (ANOVA, $\mathrm{p}<0.001)$ (Fig. 5A). There was no overall effect of salinity on ammonia concentrations

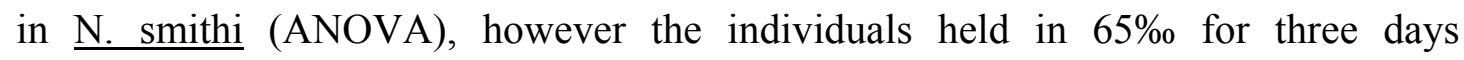
maintained lower concentrations (Fig. 5A), which were comparable to $\underline{\text { N. meinerti }}$

315 hemolymph (aside from 65\%o). Urea concentrations were not significantly different between treatments (ANOVA) and are given in figure 5B.

$\underline{\text { Field }}$

Table 2 summarizes the results of the variables measured on pore and burrow 320 water and hemolymph. Due to logistical problems, not all water samples could be

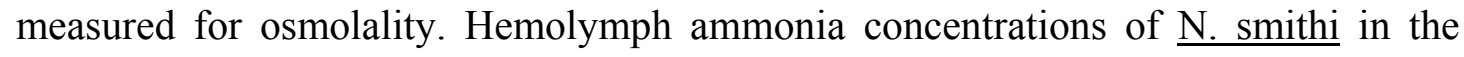
laboratory were significantly higher then those in the field (student-t, $p<0.0001$ ). The highest hemolymph ammonia concentrations in laboratory held N. meinerti (in 65\%o) were not significantly different from those at the Dabaso site (student-t).

\section{Discussion}

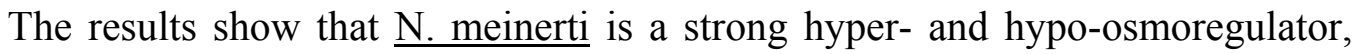
allowing them to survive in salinities from at least $16 \%$ to $65 \%$. N. meinerti appeared 
healthy at the end of the experiment as they aggressively ate during the feeding

330 experiment and had comparable feeding rates to those in the study of Emmerson and McGwynne (1992), in all salinities but 65\%. Although food consumption (FC) of $\underline{\mathrm{N}}$.

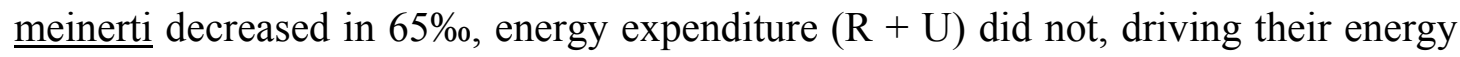

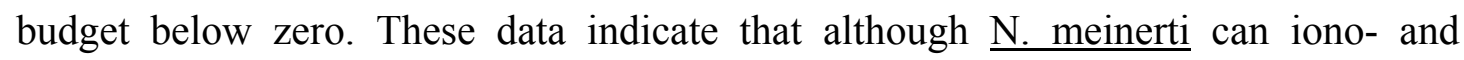
osmoregulate for one month in hypersaline conditions (Fig. 4), it is not without 335 significantly increased physiological costs, as indicated by the negative energy budget in $65 \%$ (Fig. 3D).

Mortality data distinctly show the large difference in salinity tolerance between the two congeners (Fig. 2). Data from the three individuals held at 65\% for three days

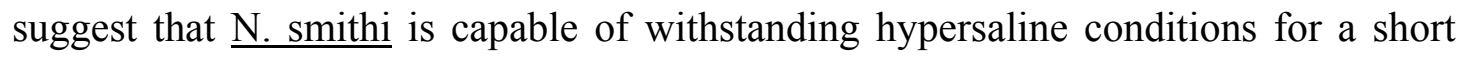
340 period ( \pm 1 week). Moreover, they survived well in $16 \%$ and $48 \%$ up to three weeks in the laboratory, with elevated mortality only during the fourth week. Due to the high mortality rate, a reliable estimation of the energy budget could not be calculated for N. smithi. The negative energy budget in the control salinity of $32 \%$ and the large difference between hemolymph ammonia of $\underline{\mathrm{N}}$. smithi in the laboratory and field 345 (Table 2 and Fig. 5A) indicates another stress factor acted on these animals. Additionally, N. smithi had overall much lower consumption rates than it's sister species, N. trispinosum, fed on a similar diet (Micheli, 1993). In both species studied, $\mathrm{Na}^{+}$and $\mathrm{Cl}^{-}$each contributed about $45 \%$ of total osmolality and thus paralleled osmolality (Fig. 4B). $\mathrm{K}^{+}$, which is not associated with volume readjustment (Gilles 350 and Pequeux, 1983), remained low and constant across salinities and was within the range reported for other crustaceans (Mantle and Farmer, 1983) (Fig. 4C). Therefore, there does not seem to be a breakdown of ionoregulation in either species. Although our calculations of the energy budget for $\underline{N}$. smithi do not seem a reliable indication of 
salt stress alone, mortality and hemolymph osmolality clearly indicate increased salt 355 stress at higher salinities.

As mortality in $16 \%$ and $48 \%$ was increased in N. smithi only later in the experiment and recent studies suggest that leaves are only a part of the diets of sesarmids and that sediment and animal matter contribute significantly to their natural diets (Bouillon et al., 2002; Skov and Hartnoll, 2002), it may be argued that the 360 overall poor condition of these animals was caused by offering an incomplete diet. Furthermore, it has been postulated that mangrove crabs eat decayed litter over senescent leaves due to the increased palatability (lower tannins) and lower C:N ratio (Giddens et al., 1986; Robertson, 1986; Micheli, 1993). However, the diet used in this experiment (green leaves) has a lower $\mathrm{C}: \mathrm{N}$ ratio than both senescent and decayed 365 leaves because the trees have not yet reabsorbed the nutrients (cf. Robertson, 1988; Rao et al., 1994). Crabs have also been shown to choose green leaves over senescent or decayed leaves (Camilleri, 1989; Greenaway and Raghaven, 1998; Ashton, 2002) and will readily consume green leaves in the field (Ashton, 2002; Gillikin, 2000). Although lack of nutrition may have played a role in the poor condition of $\underline{\mathrm{N}}$. smithi, 370 we argue that it was probably not mostly caused by offering an incomplete diet, but was a result of other stressors reducing food intake.

Mangrove leaves contain high concentrations of inorganic water-soluble salts (Cram et al., 2002) and crabs have been shown to take up salts from leaf diets (Greenaway and Linton, 1995; Greenaway and Raghaven, 1998). Therefore, we 375 believe while attempting to measure AE the main assumption of Conover (1966), that no inorganic matter is taken up via the gut, was broken. The fact that AE could not be determined challenges the reliability of these results. However, if it is assumed that 
$\mathrm{AE}$ is highest in the crabs' optimal salinity, as was found for other invertebrates (e.g. Moens and Vincx, 2000), AE would only strengthen our arguments by further

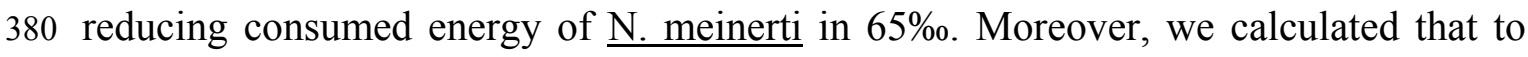
lose statistical significance of a reduced energy budget in N. meinerti in $65 \%$, as compared to the other treatments, AE would have to be at least $25 \%$ higher in the 65\% treatment, an unlikely scenario. Although AE could not be determined,

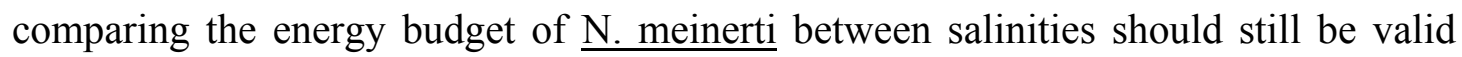
385 due to the large difference between $65 \%$ and the lower salinities and the reproducibility within the lower salinities (the energy budget of the 23 crabs in the three lower salinities was statistically indistinguishable; fig. 3D). However, it is stressed that these results are relative approximations of energy budgets and should not be extrapolated to actual field situations. changes protein structure (Withers, 1992), interferes with amino acid transport and affects many aspects of the nervous system (reviewed in Wright, 1995). In the laboratory, hemolymph ammonia concentrations ranged from $195 \pm 164$ to $970 \pm 561$

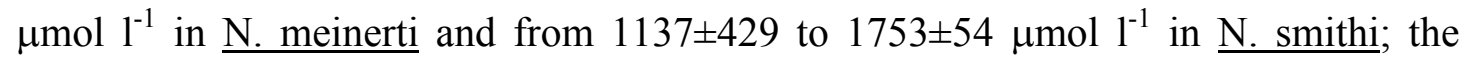
395 upper values being rare (Calybrook, 1983), but not unheard of, especially in more terrestrial crabs (cf. Wood and Boutilier, 1985). The higher hemolymph ammonia concentrations observed in $\underline{N}$. smithi held in the laboratory for one month as compared to those in the field clearly indicate the poor condition of these animals. $\underline{\mathrm{N}}$. meinerti in 65\% had high hemolymph ammonia concentrations, but still within the 400 range of those at the Dabaso site. The crabs at this site may have been experiencing excretory difficulties as there was no free burrow water present at this site and urine flow is tied to overall water balance (Greenaway, 1991). In high salt concentrations, 
however, sodium is not reabsorbed from the urine, thus affecting the ion pumps in the gills which could block ammonia excretion (Greenaway, 1991). This suggests $\underline{N}$.

405 meinerti in $65 \%$ in the laboratory, with high hemolymph ammonia concentrations and low nitrogen excretion may have been experiencing an impairment of ammonia excretion, thus compounding the effects of salt exposure.

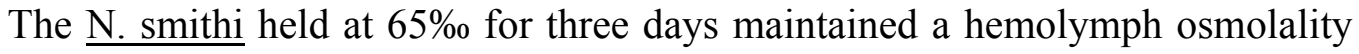

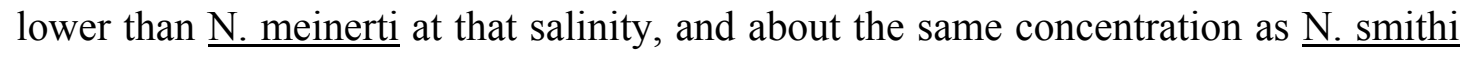
410 held in $32 \%$ for one month. As mortality data show, after about one week at this salinity, they die. This suggests that hemolymph osmolality is maintained at a fairly low concentration for a few days until the animals can no longer osmoregulate, and die. Thus, when discussing long term ecosystem change, and an animal's ability to cope with it, acute studies should only be used in the correct context. Additionally,

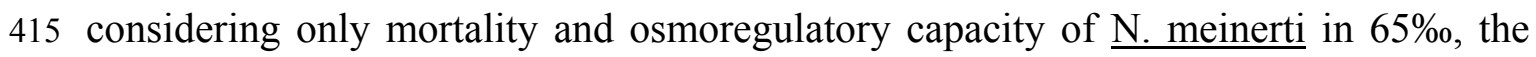
large energy expenditure needed to survive in this salinity is not evident. This may be a possible reason why Frusher et al. (1994) did not find a connection between osmoregulatory abilities and distribution in the field; they held their animals at different salinities for seven days and only measured mortality and osmoregulatory 420 capacity.

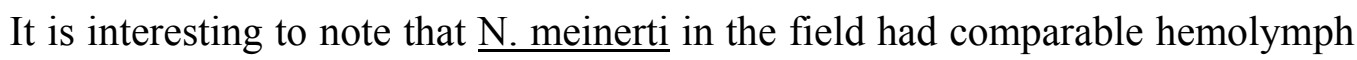
osmolality with those in $16 \%$ and $32 \%$ in the laboratory. When considering the

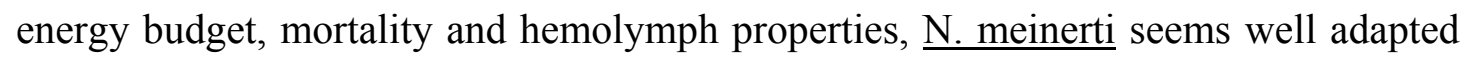
to salinities ranging from $16 \%$ to $48 \%$. N. smithi on the other hand, had highest 425 survival in $32 \%$ and hemolymph properties comparable to field populations in $16 \%$ o and $32 \%$ (see Table 2), which suggest an optimal salinity range of $16 \%$ o to $32 \%$, and 


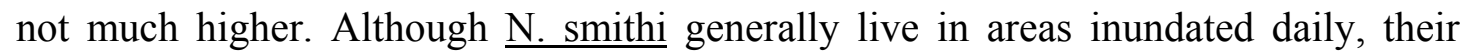
burrow water as well as ambient pore water salinity can be as high as 53\%o (Gillikin, 2000). It has been assumed that mangrove crabs commonly have higher salt tolerances 430 than mangrove trees (Jones, 1984), which would make crabs less vulnerable to salinity increases. However, our data suggest the contrary, i.e., that both Kenyan

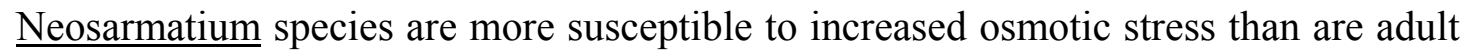
mangrove trees in general (see Chen and Twilley, 1998 and references therein for salt tolerances of adult trees), especially when living above their optimal salinity. closely related congeners (C.D. Schubart pers. com.) and can occur in close proximity to one another (Gillikin, 2000), they differ substantially in their salinity tolerances. $\mathrm{N}$.

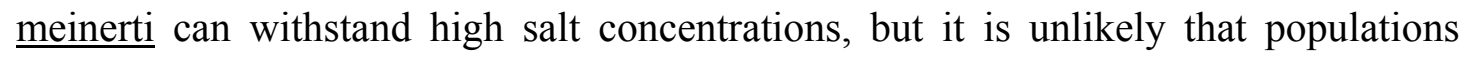
could be fully viable in hypersaline areas due to the increased energy expenditure of 440 osmoregulation. Partial groundwater redirection may or may not drastically increase salinities; however, specimens living in their upper salinity tolerance may still be effected by small changes in salinity. Where there is suitable habitat (e.g. shelter and food), crabs will tolerate living above their optimal salinity (cf. McGaw, 2001) making them more susceptible to salinity changes. Both studied species have been 445 recorded in high salinities (N. meinerti up to $65 \%$ and N. smithi up to 53\%o) in Mida Creek and Gazi Bay mangrove forests (Gillikin, 2000). The increased stress of nonoptimal salinities could make them more susceptible to other stressors such as temperature, desiccation, pollution, food shortages or disease, as was probably the case in laboratory held $\underline{\mathrm{N}}$. smithi. Such synergic effects must be taken into account 450 when considering the effects of salinity on field populations. 
As previously stated, crabs are important for mangrove ecosystems mostly due to their burrowing activities. Both species studied here are large burrowers, occurring in high densities, therefore probably placing them among the most important faunistic components of Kenyan mangrove ecosystems. If, due to increasing salinity, 455 populations would decrease or disappear, the mangrove forest could be impacted (cf. Smith et al., 1991). Groundwater flow has been shown to affect estuarine salinity regimes (see previous references), if it is altered in East Africa, these crabs may be

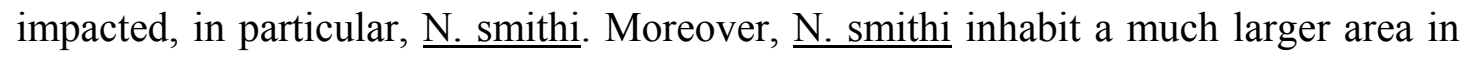
both fringe and riverine forest types (Gillikin, 2000), this and their lower salinity 460 tolerance and adaptational capacity, makes them the more critical species.

\section{Acknowledgements}

Financial support was granted by the EC project 'Anthropogenically induced changes in groundwater outflow and quality, and the functioning of Eastern African nearshore 465 ecosystems' (contract IC18-CT96-0065) and a Flemish Interuniversity Council (V.L.I.R.) travel scholarship to D.P.G. We are much indebted to Drs. A. Verheyden for both laboratory and field assistance and to Dr. F. Dehairs, Dr. S. Bouillon and anonymous reviewers for useful comments on this manuscript. Staff of the Kenya Marine and Fisheries Research Institute provided invaluable field assistance and laboratory space and gave logistical support.

470 Dr. G. Engelbosch kindly performed the calorimetric measurements on the leaves. We also with to thank Kensalt, Salt Manufactures Kenya, Ltd. for supplying natural sea-salt.

\section{References}

Anger, K., Charmantier, G., 2000. Ontogeny of osmoregulation and salinity tolerance in a 475 mangrove crab, Sesarma curacaoense (Decapoda: Grapsidae). J. Exp. Mar. Biol. Ecol. 251 (2): $265-274$. 
Ashton, E.C., 2002. Mangrove sesarmid crab feeding experiments in Peninsular Malaysia. J. Exp. Mar. Biol. Ecol. 273(1), 97-119.

Bouillon, S., Koedam, N., Raman, A.V., Dehairs, F., 2002. Primary producers sustaining macro-invertebrate communities in intertidal mangrove forests. Oecologia 130, 441-448.

Bright, D.B., Hogue, C.L., 1972. A Synopsis of the burrowing land crabs of the world and list of their symbionts and burrow associates. Contr. Sci. Nat. Hist. M 220, 1-58.

Camilleri, J.C., 1989. Leaf choice by crustaceans in a mangrove forest in Queensland. Mar. Bio. 102: 453-459.

485 Chen, R., Twilley, R.R., 1998. A gap dynamic model of mangrove forest development along gradients of soil salinity and nutrient resources. J. Ecol. 86, 37-51.

Christensen, J.D., Monaco, M.E., Lowery, T.A., 1997. An index to assess the sensitivity of Gulf of Mexico species to changes in estuarine salinity regimes. Gulf Res. Rep. 9(4), 219229.

490 Church, T.M., 1996. An underground route for the water cycle. Nature 380, 579-580.

Claybrook, D.L., 1983. Nitrogen metabolism. In: Bliss, D.E., Mantel, L.H. (eds.), The Biology of Crustacea, Internal Anatomy and Physiological Regulation, vol 5. Academic Press, New York, pp. 163-213.

Conover, R.J., 1966. Assimilation of organic matter by zooplankton. Limnol. Oceanogr. 11, $495 \quad 338-354$.

Cram, J.W., Torr, P.G., Rose, D.A., 2002. Salt allocation during leaf development and leaf fall in mangroves. Trees-Struct. Funct. 16, 112-119.

Crisp, D.J., 1971. Energy flow measurement. In: Holme, N.A., McIntyre, A.O. (eds.), Methods for the Study of Marine Benthos. Blackwell Scientific Publications, Oxford, pp. 197-279. 
Davie, P.J.F., 1994. Revision of Neosarmatium Serène and Soh (Crustacea: Brachyura: Sesarminae) with descriptions of two new species. Mem. Q. Mus. 35, 35-74.

Dixon, M., 1934. Manometric Methods as Applied to the Measurement of Cell Respiration and Other Processes. Cambridge University Press, London.

505 Elliot, J.M., Davison, W., 1975. Energy equivalents of oxygen consumption in animal energetics. Oecologia 19, 195-201.

Emmerson, W.D., McGwynne, L.E., 1992. Feeding and assimilation of mangrove leaves by the crab Sesarma meinerti de Man in relation to leaf-litter production in Mgazana, a warmtemperate southern African mangrove swamp. J. Exp. Mar. Biol. Ecol. 157, 41-53.

510 Frusher, S.D., Giddins, R.L., Smith, T.J., 1994. Distribution and abundance of Grapsid crabs (Grapsidae) in a mangrove estuary: effects of sediment characteristics, salinity tolerances, and osmoregulatory ability. Estuaries 17(3), 647-654.

Giddens, R.L., Lucas, J.S., Neilson, M.J., Richards, G.N., 1986. Feeding ecology of the mangrove crab Neosarmatium smithi (Crustacea: Decapoda: Sesarmidae). Mar. Ecol.

515 Prog. Ser. 33, 147-155.

Gillikin, D.P., 2000. Factors controlling the distribution of Kenyan brachyuran mangrove crabs: Salinity tolerance and ecophysiology of two Kenyan Neosarmatium species. MSc Thesis, Vrije Universiteit Brussel, Belgium.

Gillikin, D.P., De Grave, S., Tack, J.F., 2001. The occurrence of the semi-terrestrial shrimp 520 Merguia oligodon (De Man, 1888) in Neosarmatium smithi H. Milne Edwards, 1853 burrows in Kenyan mangroves. Crustaceana 74(5), 505-508.

Greenaway, P., Raghaven, S., 1998. Digestive strategies in two species of leaf eating land crabs (Brachyura: Gecarcinidae) in a rain forest. Physiol. Zool. 71(1), 36-44.

Greenaway, P., Linton, S.M., 1995. Dietary assimilation and food retention time in a herbivorouous terrestrial crab Gecarcoidea natalis. Physiol. Zool. 68(6), 1006-1028. 
Greenaway, P., 1991. Nitrogenous excretion in aquatic and terrestrial crustaceans. Mem. Q. Mus. 31, 215-227.

Gross, W.J., Lasiewski, R.C., Dennis, M., Rudy, P., 1966. Salt and water balance in selected crabs of Madagascar. Comp. Biochem. Physio. 17, 641-660.

530 Guerin, J.L., Stickle, W.B., 1997a. A comparative study of two sympatric species within the genus Callinectes: osmoregulation, long-term acclimation to salinity and the effects of salinity on growth and moulting. J. Exp. Mar. Biol. Ecol. 218(2),165-186.

Guerin, J.L., Stickle, W.B., 1997b. Effect of salinity on survival and bioenergetics of juvenile lesser blue crabs, Callinectes similis. Mar. Biol. 129(1), 63-69.

535 Jones, D.A., 1984. Crabs of the mangal ecosystem. In : Por, F.D. and Dor, I., (eds.) Hydrobiology of the Mangal, Dr. W. Junk Publishers, The Hauge, NL, pp. 89-109.

Kamermans, P., Hemminga, M.A., Tack, J.F., Mateo, M.A., Marbà, N., Mtolera, M., Stapel, J., Verheyden, A., Van Daele, T., 2002. Groundwater effects on diversity and abundance of lagoonal seagrasses in Kenya and on Zanzibar Island (East Africa). Mar. Ecol. Prog. Ser. $231,75-83$.

Kitheka, J.U., 1998. Groundwater outflow and its linkages to coastal circulation in a mangrove-fringed creek in Kenya. Estuar. Coast. Shelf Sci. 47(1), 63-75.

Kitheka, J.U., Mwashote, B.M., Ohowa, B.O., Kamau, J., 1999. Water circulation, groundwater outflow and nutrient dynamics in Mida creek, Kenya. Mangroves and Salt Marshes 3, 135-146.

Lee, S.Y., 1997. Potential trophic importance of the faecal material of the mangrove crab Sesarma messa. Mar. Ecol. Prog. Ser. 159, 275-284.

Lee, S.Y., 1998. Ecological role of grapsid crabs in mangrove ecosystems: a review. Mar. Freshw. Res. 49, 335-343. 
550 Lee, W.C, Chen, J.C., 2003. Hemolymph ammonia, urea and uric acid levels and nitrogenous excretion of Marsupenaeus japonicus at different salinity levels J. Exp. Mar. Biol. Ecol. $288,39-49$.

Leith, H., Berlekamp, J., Fuest, S., Riediger, S., 1999. Climate diagram world atlas. CDseries: Climate and biosphere. Leith, H. (ed.). $1^{\text {st }}$ ed. 7/1999. Backhuys Publishers, Leiden.

555 McGaw, I.J., 2001. Impacts of habitat complexity on physiology: purple shore crabs tolerate osmotic stress for shelter. Est. Coast. Shelf. Sci. 52, 865-876.

Micheli, F., 1993. Feeding ecology of mangrove crabs in North Eastern Australia: mangrove litter consumption by Sesarma messa and Sesarma smithii. J. Exp. Mar. Biol. Ecol. 171, $165-186$.

560 Micheli, F., Gherardi, F., Vannini, M., 1991. Feeding and Burrowing Ecology of Two East African Mangrove Crabs. Mar. Biol. 111, 247-254.

Moens, T., Vincx, M., 2000. Temperature, salinity and food thresholds in two brackish-water bacterivorous nematode species: assessing niches from food absorption and respiration experiments. J. Exp. Mar. Biol. Ecol. 243(1), 137-154.

565 Moore, W.S., 1996. Large groundwater inputs to coastal waters revealed by $226 \mathrm{Ra}$ enrichments. Nature 380, 612-614.

Rahmatullah, M., Boyde, T.R.C., 1980. Improvements in the determination of urea using diacetyl monoxime; methods with and without deproteinisation. Clin. Chim. Acta 107(12), 3-9.

570 Rao, R., Woitchik, A.F., Goeyens, L., Van Riet, A., Kazungu, J., Dehairs, F., 1994. Carbon, nitrogen contents and stable carbon isotope abundance in mangrove leaves from an East African coastal lagoon (Kenya). Aquat. Bot. 47(2), 175-183.

Ridd, P.V., 1996. Flow through animal burrows in mangrove creeks. Estuar. Coast. Shelf Sci. $43,617-625$. 
575 Robertson, A.I., 1986. Leaf-burying crabs: their influence on energy flow and export from mixed mangrove forests (hizophora spp.) in northeastern Australia. J. Exp. Mar. Biol. Ecol. 102, 237-248.

Robertson, A.I., 1988. Decomposition of mangrove leaf litter in tropical Australia. J. Exp. Mar. Biol. Ecol. 116, 235-247.

580 Robertson, A.I., Daniel, P.A., 1989. The influence of crabs on litter processing in high intertidal mangrove forests in tropical Australia. Oecologia 78, 191-198.

Schubart, C. D., Diesel, R., 1998. Osmoregulatory capacities and penetration into terrestrial habitats: A comparative study of Jamaican crabs of the genus Armases Abele, 1992 (Brachyura: Grapsidae: Sesarminae). B. Mar. Sci. 62(3), 743-752.

585 Skov, M.W., Hartnoll, R.G., 2002. Paradoxical selective feeding on a low-nutrient diet: why do mangrove crabs eat leaves? Oecologia 131, 1-7.

Smith, T.J., Boto, K.G., Frusher, S.D., Giddens, R.L., 1991. Keystone species and mangrove forest dynamics: the influence of burrowing by crabs on soil nutrient status and forest productivity. Estuar. Coast. Shelf Sci. 33(5), 419-432.

590 Solorzano, L., 1969. Determination of ammonia in natural waters by the phenolhypochlorite method. Limnol. Oceanogr. 14, 799-801.

Stieglitz, T., Ridd, P., Müller, P., 2000. Passive irrigation and functional morphology of crustacean burrows in a tropical mangrove swamp. Hydrobiologia 421, 69-76.

Tack, J.F., Polk, P., 1999. The Influence of tropical catchments upon coastal zone: modelling 595 the links between groundwater and mangrove losses in Kenya, India/Bangladesh and Florida, In: Harper, D., Brown, T. (eds.), The Sustainable Management of Tropical Catchments. J. Wiley, London, pp. 359-371

Vercauteren, K., Blust, R., 1996. Bioavailability of dissolved zinc to the common mussel Mytilus edulis in complexing environments. Mar. Ecol. Prog. Ser. 137, 123-132. 
600 Warren, J.H., Underwood, A.J., 1986. Effects of burrowing crabs on the topography of mangrove swamps in New South Wales. J. Exp. Mar. Biol. Ecol. 102, 223-236.

Winberg, C.G., 1960. Rate of metabolism and food requirements of fishes. Transl. Ser. Fish. Res. Bd. Can. 194, 202.

Withers, P.C., 1992. Comparative animal physiology. Saunders College Publishing, New 605 York.

Wood, C.M., Boutilier, R.G., 1985. Osmoregulation, ionic exchange, blood chemistry and nitrogenous waste in the land crab Cardisoma carnifex: a field and laboratory study. Biol. Bull. Mar. Biol. Lab. Woods Hole. 169, 267-290.

Wright, P.A., 1995. Nitrogen excretion: three end products, many physiological roles. J. Exp. 610 Biol. 198, 273-281. 
Table 1. Percent of all 'eaten' leaves (see text) measured on consecutive days.

\begin{tabular}{lcccc}
\hline Species & Day & $\begin{array}{l}\mathrm{Rm} \\
\%\end{array}$ & $\begin{array}{l}\mathrm{Ct} \\
\%\end{array}$ & $\begin{array}{l}\mathrm{Am} \\
\%\end{array}$ \\
\hline \hline Neosarmatium & 1 & 73 & 24 & 3 \\
smithi & 2 & 88 & 12 & 0 \\
& 3 & 50 & 44 & 6 \\
Neosarmatium & 1 & 21 & 11 & 68 \\
meinerti & 2 & 31 & 15 & 54 \\
& 3 & 28 & 26 & 46 \\
& 4 & 23 & 23 & 54 \\
\hline
\end{tabular}

$\mathrm{Rm}=$ Rhizophora mucronata, $\mathrm{Ct}=$ Ceriops tagal, $\mathrm{Am}=$ Avicennia marina. 
Table 2. Means and standard deviations of ion concentrations, osmotic pressure, ammonia and urea in pore water (PW), burrow water (BW) and hemolymph (HL) measured in the field.

\begin{tabular}{|c|c|c|c|c|c|c|c|c|}
\hline Species & $\begin{array}{l}\text { Location } \\
\text { \& salinity }\end{array}$ & Type & $\begin{array}{c}\mathrm{Na}^{+} \\
\mathrm{mmol} \mathrm{I}^{-1}\end{array}$ & $\begin{array}{c}\mathrm{K}^{+} \\
\mathrm{mmol} \mathrm{I}^{-1}\end{array}$ & $\begin{array}{c}\mathrm{Cl}^{-} \\
\mathrm{mmol} \mathrm{I}^{-1}\end{array}$ & $\begin{array}{c}\mathrm{NH}_{4}^{+} \\
\mathrm{\mu mol} \mathrm{I}^{-1}\end{array}$ & $\begin{array}{c}\text { Urea } \\
\mu_{\mathrm{mol} \mathrm{I}}^{-1}\end{array}$ & $\begin{array}{c}\text { Osmolality } \\
\text { mOsm }\end{array}$ \\
\hline N. meinerti & Dabaso & PW & $491 \pm 58$ & $10.5 \pm 1.5$ & $546 \pm 68$ & $28 \pm 64$ & $16 \pm 26$ & $1179 \pm 37$ \\
\hline$(n=11)$ & (37-39) & HL & $341 \pm 30$ & $11.1 \pm 4.8$ & $328 \pm 30$ & $807 \pm 488$ & $31 \pm 42$ & $781 \pm 69$ \\
\hline \multirow{3}{*}{$\begin{array}{l}\text { N. meinerti } \\
(\mathrm{n}=9)\end{array}$} & Gazi & BW & $637 \pm 151$ & $13.3 \pm 2.7$ & $714 \pm 167$ & $73 \pm 120$ & $24 \pm 13$ & $\mathrm{~nm}$ \\
\hline & $(20-65)$ & PW & $825 \pm 28$ & $16.3 \pm 0.7$ & $924 \pm 32$ & $2 \pm 5$ & $9 \pm 6$ & $\mathrm{~nm}$ \\
\hline & & $\mathrm{HL}$ & $340 \pm 27$ & $12.0 \pm 2.7$ & $331 \pm 32$ & $565 \pm 313$ & $24 \pm 18$ & $752 \pm 64$ \\
\hline \multirow{3}{*}{$\begin{array}{l}\text { N. meinerti } \\
(\mathrm{n}=12)\end{array}$} & Gazi & BW & $382 \pm 22$ & $8.5 \pm 0.6$ & $423 \pm 24$ & $19 \pm 25$ & $7 \pm 4$ & $\mathrm{~nm}$ \\
\hline & $(23-30)$ & PW & $443 \pm 48$ & $9.6 \pm 1.2$ & $481 \pm 43$ & $5 \pm 7$ & $10 \pm 6$ & $1039 \pm 27$ \\
\hline & & $\mathrm{HL}$ & $327 \pm 10$ & $9.2 \pm 1.1$ & $322 \pm 12$ & $346 \pm 131$ & $14 \pm 9$ & $729 \pm 40$ \\
\hline N. smithi & Dabaso & BW & $534 \pm 98$ & $11.7 \pm 2.2$ & $584 \pm 104$ & $71 \pm 34$ & $40 \pm 31$ & $1122 \pm 134$ \\
\hline \multirow[t]{2}{*}{$(n=10)$} & $(31-38)$ & PW & $499 \pm 38$ & $10.7 \pm 0.9$ & $552 \pm 41$ & $28 \pm 20$ & $9 \pm 6$ & $1150 \pm 73$ \\
\hline & & $\mathrm{HL}$ & $382 \pm 11$ & $10.4 \pm 1.1$ & $368 \pm 17$ & $601 \pm 268$ & $52 \pm 78$ & $815 \pm 61$ \\
\hline \multirow{3}{*}{$\begin{array}{l}\text { N. smithi } \\
(\mathrm{n}=12)\end{array}$} & Gazi & BW & $423 \pm 39$ & $9.2 \pm 0.8$ & $472 \pm 42$ & $87 \pm 61$ & $13 \pm 10$ & $1020 \pm 105$ \\
\hline & $(27-35)$ & PW & $428 \pm 37$ & $9.2 \pm 1.0$ & $477 \pm 41$ & $113 \pm 59$ & $13 \pm 11$ & $896 \pm 126$ \\
\hline & & HL & $373 \pm 13$ & $10.8 \pm 1.9$ & $365 \pm 11$ & $499 \pm 229$ & $43 \pm 47$ & $785 \pm 25$ \\
\hline
\end{tabular}

$\mathrm{n}=$ number of individuals sampled; salinity $=$ salinity range of available water in $\%$; $\mathrm{nm}=$ not measured. 


\section{FIGURE CAPTIONS}

FIGURE 1. Map of the Kenyan coast with study areas indicated.

FIGURE 2. Number of crabs out of 10 surviving at the end of each week in each salinity during the acclimation period (first week is the step-wise acclimation to target salinity) $($ gray $=16 \%$, hatched $=32 \%$, white $=48 \%$, black $=65 \%$ ).

FigurE 3. Means and standard deviations of food consumption (A), nitrogen excretion (B), oxygen consumption (C) and energy budgets (D) in Neosarmatium

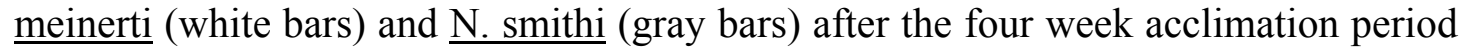
in four salinities. Numbers above bars are salinities which were significantly different $(*=\mathrm{p}<0.05, * *=\mathrm{p}<0.01, * * *=\mathrm{p}<0.001)$.

Figure 4. Means and standard deviations of hemolymph osmotic pressure (A), $\mathrm{Na}^{+}$ (black) and $\mathrm{Cl}^{-}$(gray) (B) and $\mathrm{K}^{+}(\mathrm{C})$ of Neosarmatium meinerti $(\boldsymbol{A})$ and $\underline{\mathrm{N} \text {. smithi }}$ (•) after the four week acclimation period in each salinity. Data from N. smithi held at $65 \%$ for three days are also given $(0)$. The isosmotic line is shown as diagonal.

FIGURE 5. Means and standard deviations of hemolymph ammonia (A) and urea (B)

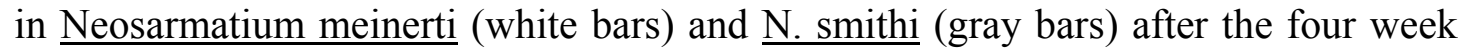

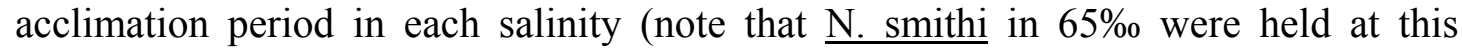
salinity for only three days). Numbers above bars are salinities which were significantly different $(*=\mathrm{p}<0.05, * *=\mathrm{p}<0.01, * * *=\mathrm{p}<0.001)$. 


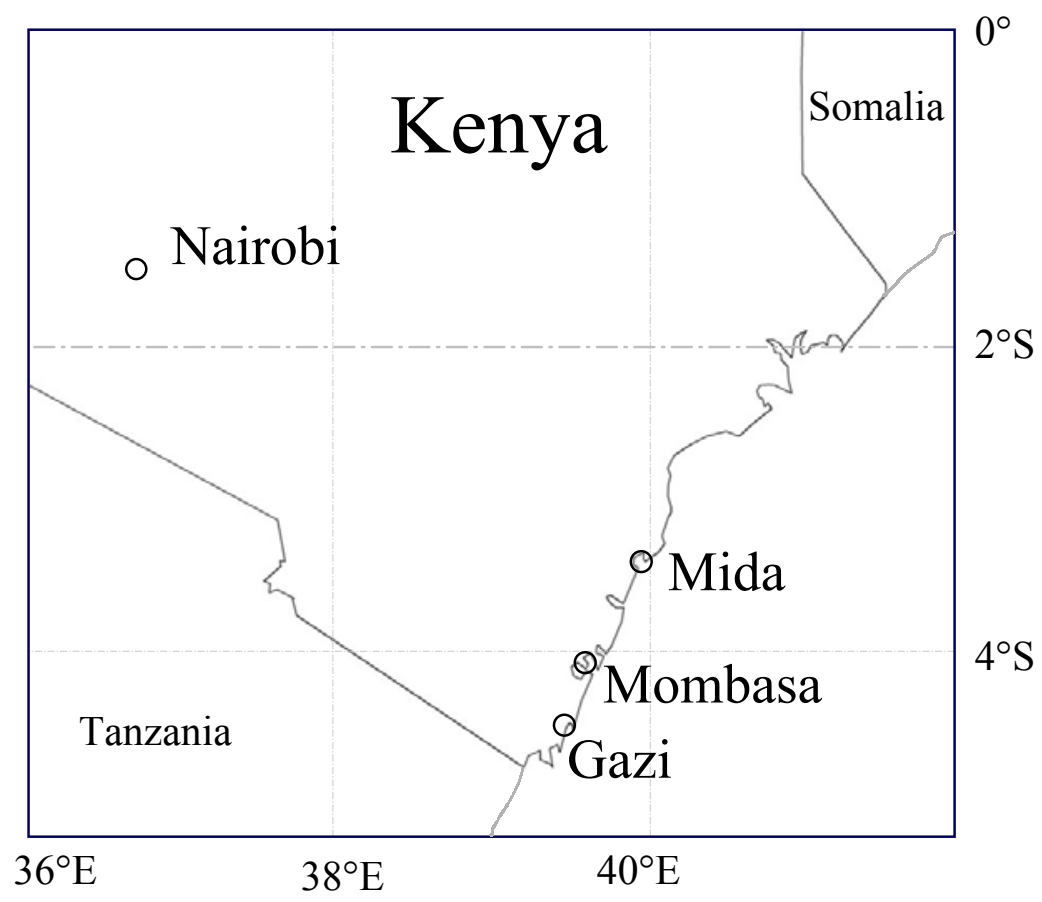




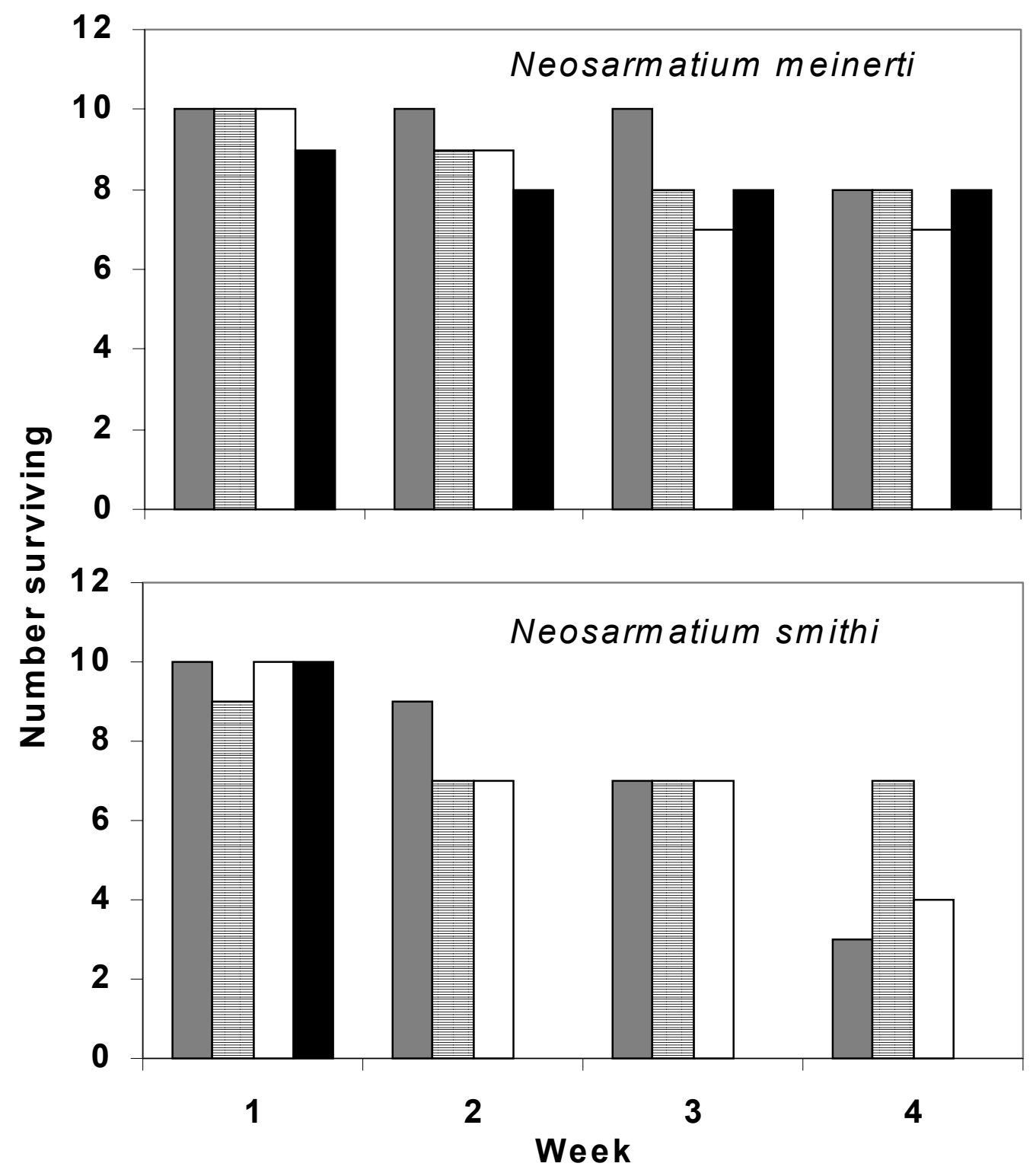



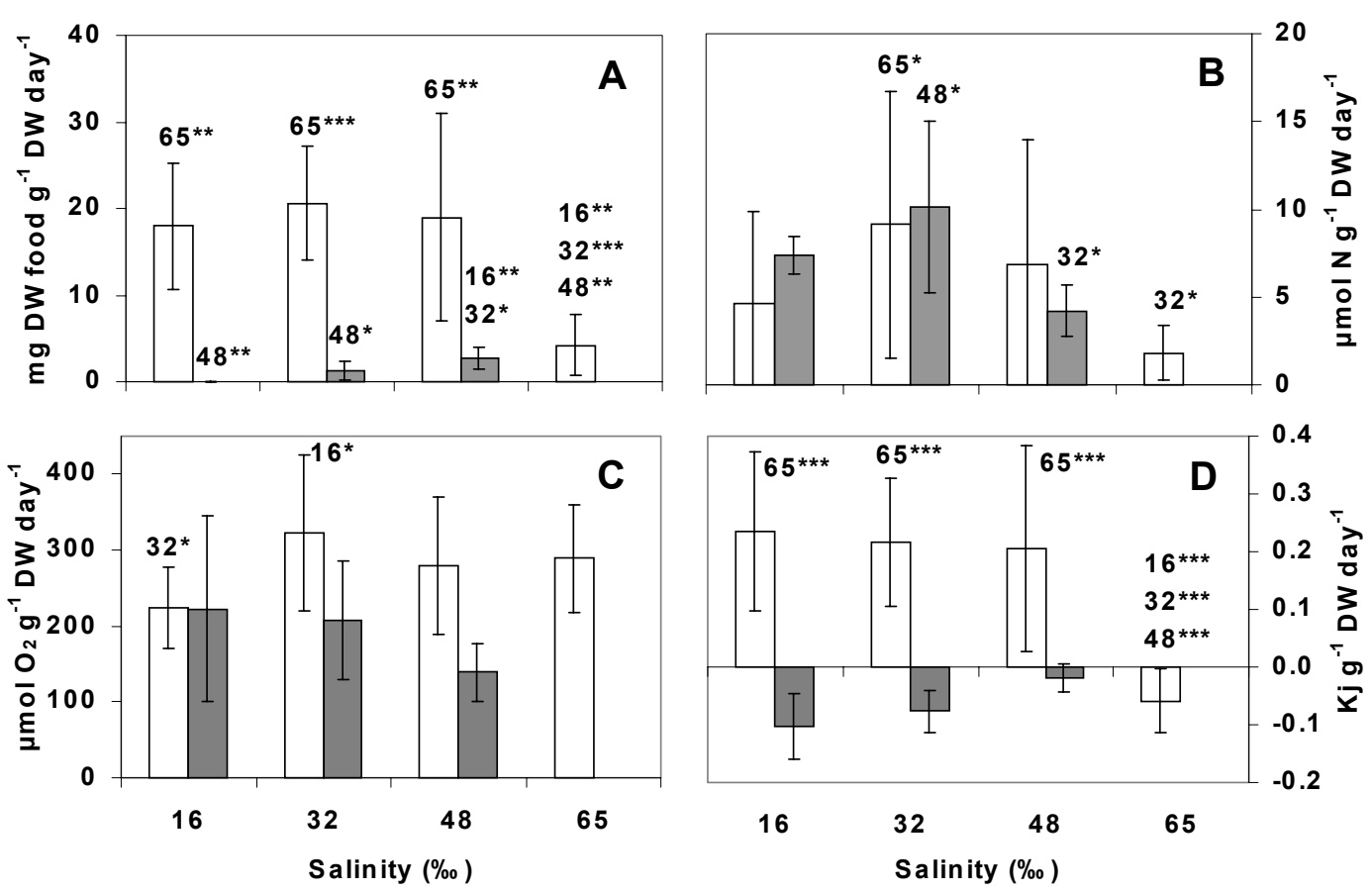

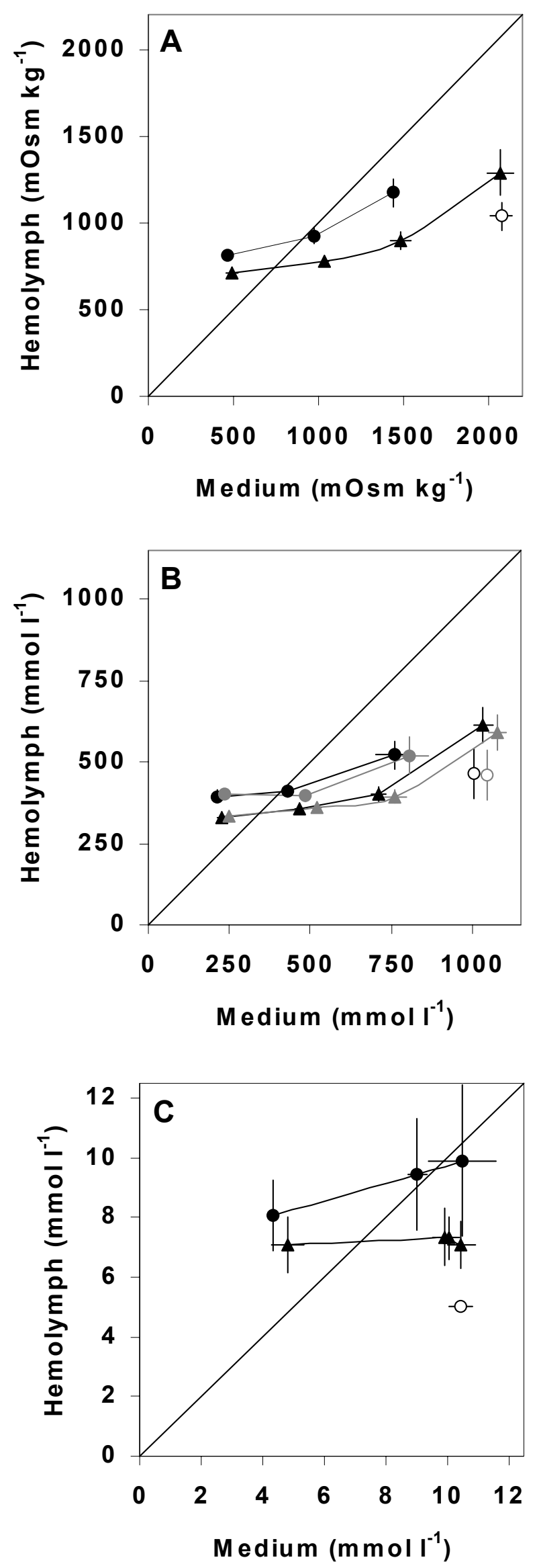

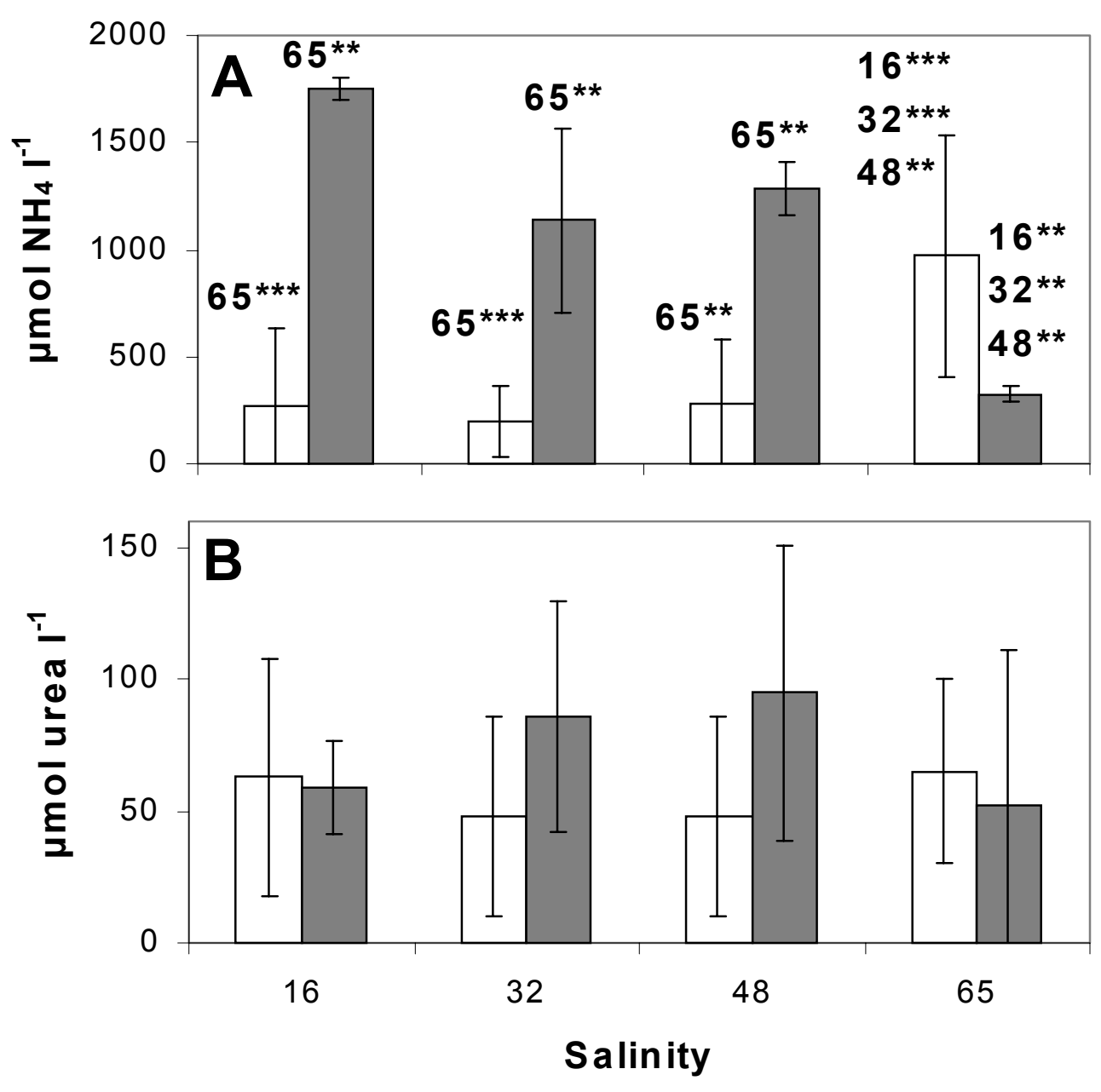